\title{
A Review and Classification of Most Used MPPT Algorithms for Photovoltaic Systems
}

\author{
Omer Faruk Tozlu' ${ }^{10}$ Huseyin Calik ${ }^{2}$ (D) \\ ${ }^{1}$ Hitit University, Department of Electrical and Electronics Engineering, Corum, Turkey \\ ${ }^{2}$ Giresun University, Department of Electrical and Electronics Engineering, Giresun, Turkey
}

A B S T R ACT
nergy has become an indispensable need to sustain our lives. Approximately $80 \%$ of the
depletion of fossil resources and their damages to the environment, the interest in renewable
resources is increasing and the importance of solar systems, which draws attention with un-
limited energy resource, is increasing day by day. The biggest disadvantages of solar systems
are seen as low production efficiency and high setup cost. A PV cell can convert only $5-20 \%$
of the solar energy coming on it to electricity. Based on this, it is very important to provide
the power obtained from PV with maximum efficiency and minimum cost. Accordingly,
many different maximum power point tracking (MPPT) algorithms have been proposed
over the years. Although the purpose of all proposed algorithms is the same, they have many
advantages and disadvantages compared to each other. In this study, the most used MPPT al-
gorithms have been examined and compared by considering many parameters such as track-
ing speed, stability, and cost etc. and a new classification of these algorithms is proposed.

\author{
Article History: \\ Received: 2021/03/01 \\ Accepted: 2021/07/01 \\ Online: $2021 / 09 / 29$ \\ Correspondence to: Ömer Faruk Tozlu, \\ Deparment of Electrical and Electronics \\ Engineering, Hitit University, Çorum, \\ Turkey \\ Tel: +903642274533 \\ E-Mail:omerfaruktozlu@hitit.edu.tr
}

Keywords:

MPPT; Photovoltaic; Incremental conductance; Perturb and observe; Intelligent methods; Particle swarm optimization

\section{INTRODUCTION}

$\mathrm{E}$ nergy, which can be defined as the ability to do work in its basic form, is in an indispensable position to sustain human life, meet their needs, and increase the quality of life. Over time, there is a serious increase in the total energy consumed in the world due to many reasons such as the increase in the human population, changes in people's lifestyle, increase in production, and technological developments. Energy production should be increased in order to meet the energy needs. Approximately $80 \%$ of the energy produced in the world is produced in power plants where natural gas and coal are used as the main energy source [1]. It is thought that toxic gases such as carbon, sulfur, heavy metals mixed into the soil and many other wastes released into the atmosphere during energy production from these limited fossil resources on earth will have negative effects on nature and living things over the years. Renewable energy sources, especially solar energy, are seen as an important alternative here. Because the sun sends more than the energy consumed in the world as clean energy every day. Solar energy has gained a place as a serious choice with its advantages such as very low operating and maintenance costs and being the most ecofriendly energy. In addition to all these advantages, it also has disadvantages such as low efficiency, especially in energy conversion, and high setup cost. Numerous studies are carried out in order to obtain maximum efficiency from photovoltaic (PV) panels [2-4].

Solar energy is produced by converting the photon energy carried by the light coming to the surface of the panels formed by the combination of photovoltaic cells, into electric current by p-n junction in these cells. As the wavelength of the light gets shorter, the amount of energy carried by the photon increases. On the other hand, the angle of the light that comes to the panel is also very important. The angle of the sunray comes on the earth constantly changes during the day. Consequently, the amount of radiation absorbed by the solar panel (photovoltaic cells) will also change, so the energy obtained will be different at each time interval. PV cells can basically be compared to a p-n junction diode. The equivalent circuit model of the PV cell was described by Lorenzo in 1994 [5]. This model consists of a current source and a parallel diode connected to it. Here, the series resistance $\left(R_{s}\right)$ refers to the internal losses of the 


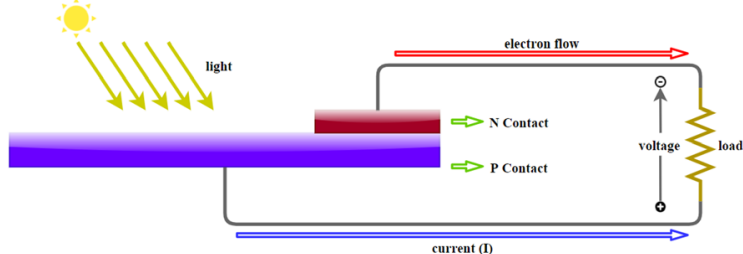

Figure 1. Basic structure of the PV cell

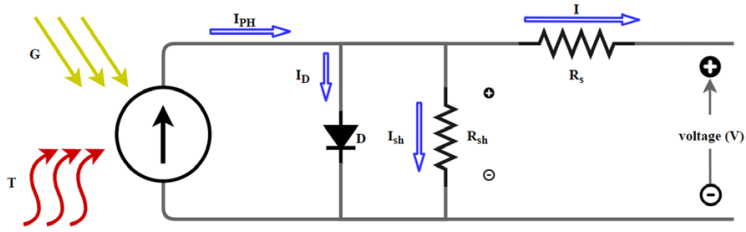

Figure 2. Equivalent circuit of PV cell

solar cell caused by the current flow and it is desired to be minimized for maximum power generation. The $\left(\mathrm{R}_{\mathrm{sh}}\right)$ resistance connected in parallel to the diode refers to the losses caused by the leakage currents to the ground, it is generally neglected because the current value is too low, and the resistance value is too high. The basic structure of the PV cell is shown in Fig. 1 and its equivalent circuit in Fig. 2.

The equations expressing the current and voltage of the PV cell are given below. Here, the series resistance $\left(R_{s}\right)$, ideality factor $(n)$, and parallel resistance $\left(R_{\text {sh }}\right)$ are parameters that vary according to the characteristics of the PV cell. Other parameters are Boltzmann constant $(\mathrm{k})$, electron charge (q), and solar cell temperature (T). IPH refers to the photon current and IS to the saturation current.

$I=I_{P H}-I_{S}\left[\exp \left(\frac{q}{n \cdot k \cdot T}\left(V+R_{s} \cdot I\right)\right)-1\right]-\frac{V+R_{s} \cdot I}{R_{s h}}$

The equation of IPH current based on radiation and temperature is given below. In the atmospheric conditions specified with the standard test condition (STD) here, the ambient temperature is $25^{\circ} \mathrm{C}$, the radiation is $1000 \mathrm{~W} / \mathrm{m}^{2}$, and the air mass is 1.5 . $\mathrm{T}$ temperature, $\mathrm{G}$ radiation, and $\mathrm{K}_{\mathrm{I}}$ represent the temperature coefficient of the $\mathrm{I}_{\mathrm{sc}}$.

$$
\begin{gathered}
I_{P H}=\left(I_{S C_{-} S T D}+K_{I}\left(T-T_{S T D}\right)\right) \cdot \frac{G}{G_{S T D}} \\
V=\frac{n \cdot k \cdot T}{q} \ln \left(\frac{I_{P H}+I_{S}-I}{I_{S}}\right)-R_{s} \cdot I
\end{gathered}
$$

When the necessary negligence and simplifications are made, the I-V characteristic of a PV cell, shown in Fig. 3, can be written with the Shockley diode equation below.

$$
I_{D}=I_{S} \cdot \exp \left(\frac{q V}{k T}-1\right)
$$

The point where the maximum power is transferred to the load is called the maximum power point (MPP) and this

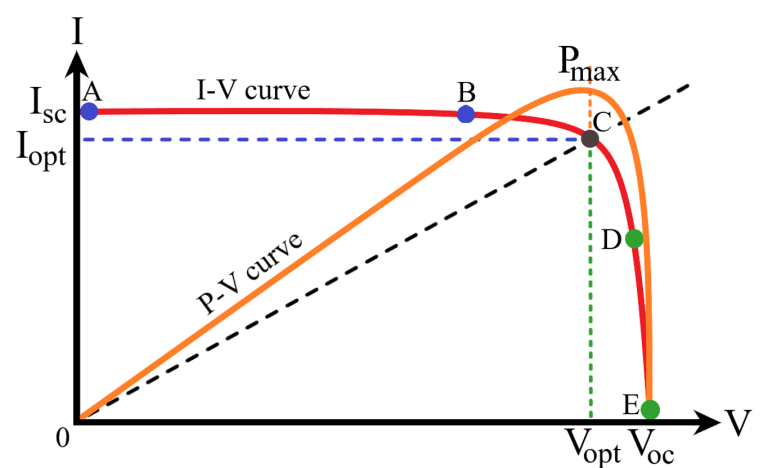

Figure 3. Typical current-voltage characteristics of the PV cell

is the point $\mathrm{C}\left(\mathrm{I}_{\text {opt }}, \mathrm{V}_{\text {opt }}\right)$ in Fig. 3. The suitable value received by the load for this point is $\mathrm{R}_{\text {opt }}$. The maximum power $\mathrm{P}_{\max }$ can be written as follows:

$$
P_{\max }=V_{o p t} \cdot I_{o p t}=I_{o p t}^{2} \cdot R_{o p t}=\frac{V_{o p t}^{2}}{R_{o p t}}
$$

The load characteristic can be found linearly as the slope of $I / V=1 / R$ for an ohmic load. It can be said that the power transferred to the load depends only on the resistance. Accordingly, if the load R is too low, the PV cell will operate close to the $\mathrm{I}_{\mathrm{sc}}$ as a current source in the A-B range in Fig. 1. If the load $\mathrm{R}$ is quite high, then the solar cell will operate at a value close to the $\mathrm{V}_{\text {oc }}$ as a constant voltage source in the D-E range of the curve [6]. For the system to function correctly, an increasing and decreasing irregular power supply cannot be given directly to the load. These power values need to be made regular and efficient. MPPT is used to perform this process. In other words, the purpose of MPPT is to obtain maximum power from PV panels in all conditions by matching the I-V operating point with the load characteristics [7]. The delivered power can be maximized by regulating the current or voltage of the PV panel to force the converter operate at the MPP $[8,9]$.

PV systems always have a DC-DC converter. MPPT controls the DC-DC converter, forcing the PV system to operate at MPP. Fig. 4 shows the operating scheme of the MPPT system. The MPPT usually measures the input and/ or output voltage/current of the PV, and it sends a suitable control signal to the DC-DC converter by processing this data to operate the system in MPP. Here, the measured data is processed with the help of reference values, the error is detected, and the DC-DC converter is controlled with the appropriate PWM signals adjusted by modifying the duty cycle for the point where the maximum power can be obtained.

Over the years, Perturb and Observe (P\&O) [7,11-13], Incremental Conductance (IncCond) [14-18], Fuzzy Logic [19-21] etc. many different MPPT algorithms have been proposed. Although the purpose of all proposed algorithms is the same, they have many advantages and disadvantages 


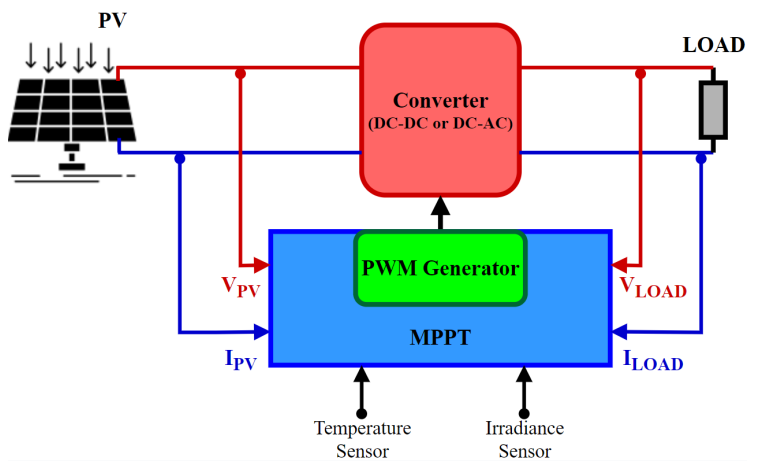

Figure 4. Operating scheme of the MPPT system [10]

compared to each other. In this study, MPPT algorithms, accepted in the literature, were examined, and compared considering many parameters such as speed, complexity and cost etc. A new classification of MPPT algorithms is proposed.

\section{MPPT ALGORITHMS}

In order to obtain maximum power and efficiency from the PV panel, many methods are proposed, and each of these methods has different advantages and disadvantages. Therefore, the most appropriate method should be chosen for each system. Here, many parameters such as the atmospheric conditions of the region where the system will be installed, sunshine duration, and the budget allocated to the system should be taken into consideration.

MPPT methods can be classified by different names. There are different approaches in these classifications such as the characteristics of the algorithm and tracking method. Generally, these are divided into classes such as indirect, direct, soft computing, or conventional, inteligent methods depending on the method of application [2,22-24]. MPPT algorithms can be classified under headings such as constant parameters, measurement-and-comparison, mathematical calculation, trial-and-error, and intelligent according to the tracking method [25]. In indirect methods, MPP is calculated with simple assumptions without measuring the power of the PV. In direct methods, parameters such as power, voltage, and current of PV are measured with the help of sensors and MPP is determined with processing these measured values.

The most used classification is divided MPPT algorithms into two class as conventional and intelligent. In this paper, MPPT algorithms are examined according to this classification and a new classification is proposed.

\section{Conventional Methods Constant Voltage (CV)}

The simplest MPPT method, CV, is applied by fixing the PV voltage to a value close to the VMPP reference value. The PV voltage is measured, compared with VMPP, an error is found, and the voltage is adjusted according to the error. The flowchart of the method is shown in Fig. 5. In this method, true MPP cannot be achieved because the effect of temperature and radiation are not included in the algorithm. The most important advantage of this method is that it is more efficient than many more expensive methods under low radiation [26]. Due to this feature, it is preferred in some cases.

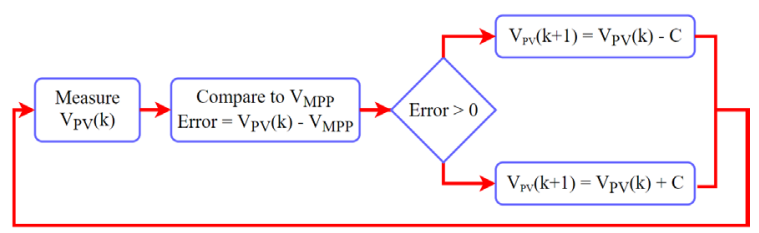

Figure 5. Constant voltage method flowchart

\section{Fractional Open-Circuit Voltage (FOCV)}

The $\mathrm{V}_{\text {oc }}$ shown in Fig. 3 expresses the open circuit voltage of the PV panel. In the FOCV, the $\mathrm{V}_{\text {oc }}$ at the ends of the PV panel is measured, and multiplied with a certain coefficient to find the Vopt [27]. The equation between $V_{\text {oc }}$ and $\mathrm{V}_{\text {opt }}$ is expressed as follows:

$$
V_{o p t}=V_{o c} \cdot k_{o c} \quad\left(0<k_{o c}<1\right)
$$

Here, $\mathrm{k}_{\text {oc }}$ coefficient depends on factors such as the production technology of the panel and atmospheric conditions. The optimum voltage usually corresponds to $76 \%$ of the open circuit voltage. Researches have shown that the $\mathrm{k}_{\mathrm{oc}}$ value is in the range of $0.73-0.80$ [28]. The key disadvantage of the method whose flowchart shown in Fig. 6 is that the PV power has to be cut off suddenly to measure the $\mathrm{V}_{\text {oc }}$ [29]. It is preferred in some cases due to its low cost and simple application.

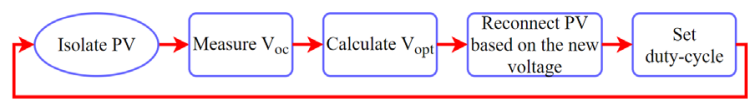

Figure 6. Fractional open-circuit voltage method flowchart

\section{Open-Circuit Voltage with Pilot PV Cell (FOCVPVC)}

The method is same as the FOCV. The only difference here is that instead of making the entire panel open circuit, $\mathrm{V}_{\text {opt }}$ is calculated over the $\mathrm{V}_{\text {oc }}$ of a single cell, independent of other cells, and named as a pilot. Thus, interruptions during voltage measurement, one of the most important disadvantages of the FOCV, are prevented. 
However, it works more inefficiently in cases such as partial shading $[26,30]$.

\section{Fractional Short-Circuit Current (FSCC)}

In this method, which is very similar to the FOCV, $\mathrm{I}_{\text {opt }}$ is calculated by measuring the $\mathrm{I}_{\mathrm{sc}}$ of the PV [31]. The relationship between short circuit current and optimum current is given below:

$$
I_{o p t}=I_{s c} \cdot k_{s c} \quad\left(0<k_{s c}<1\right)
$$

Here, $\mathrm{k}_{\mathrm{sc}}$ coefficient depends on same conditions. The optimum current generally corresponds to $86 \%$ of the open circuit current. Researches have shown that the $\mathrm{k}_{\mathrm{sc}}$ value is in the range of 0.78-0.92 [32]. In FSCC whose flowchart shown in Fig. 7, it is more difficult to determine $\mathrm{I}_{\mathrm{sc}}$ because of heat dissipation and increase in power loss. It may not always be physically possible to short circuit the system. In addition, additional materials such as switches and current sensors may be needed [33]. This increases the cost and the loss in energy produced. For these reasons, the FOCV is more preferred between these simple two methods.

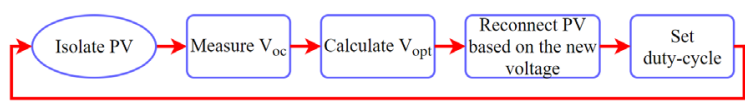

Figure 7. Fractional short-circuit current method flowchart

\section{Look-up Table (LUT)}

In the LUT whose flowchart is given in Fig. 8, the data of PV under all possible atmospheric conditions is recorded and a table is created. A new $\mathrm{V}_{\text {opt }}$ value is determined in each round by comparing the actual values with the saved ones. In the LUT, since it is assumed that the actual conditions of the PV are the conditions in which the data in the table is recorded, in some cases the $\mathrm{V}_{\text {opt }}$ may not be determined correctly enough [12]. As the table expands, the efficiency and the system memory needed increase. Since increasing the system memory will increase the cost, tables with optimum dimensions are preferred and some possible conditions are neglected. This situation negatively affects the capture of MPP $[34,35]$.

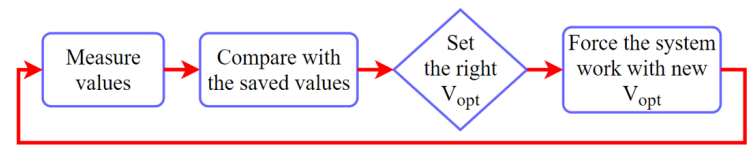

Figure 8. Look-up table method flowchart

\section{Load Current or Load Voltage Maximization (LCLVM)}

In this method, it is assumed that when the output power is maximized in a lossless converter, the input power will also be maximized. Load voltage or current is maximized depending on the characteristics of the load. Thus, it is assumed that the input power also reaches its maximum.
One of the major disadvantages of the method is that the converter is not lossless, so MPP cannot be fully tracked. By increasing the quality of the converter, the loss can be minimized, but this will increase the cost $[36,37]$.

\section{PV Output Senseless (POS)}

The flowchart of the method, generally used in large-scaled systems, is shown in Fig. 9. In large-scaled PV systems, the voltage drop at the output is negligible. In this case, the maximum power can be considered directly proportional to the maximum current. In POS, the old and new duty-cycle data are compared, and the load current is taken as a feedback, thus minimizing the error [38]. One of the major advantages of the method, which responds quickly to sudden atmospheric changes and shading, is that the system does not require any measurement from the PV side [39].

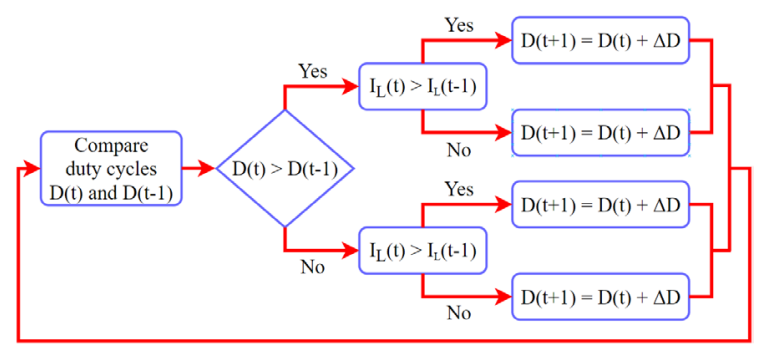

Figure 9. PV output senseless flowchart

\section{Perturb and Observe (P\&O)}

In the $\mathrm{P} \& \mathrm{O}$, which is one of the most widely used methods among all MPPT algorithms, MPP or the closest point to MPP is found by trial-and-error method. The most important reason for its widespread use is that it can be easily applied to any system regardless of its PV properties and it can find MPP with acceptable accuracy at low cost. The flowchart of the $\mathrm{P} \& \mathrm{O}$ method is shown in Fig. 10. In the method, PV power is calculated with the measured voltage and current of the panel. According to the change in PV power, it is decided what to do next. If an increase in the obtained power is detected, the operating voltage continues to be increased or decreased in the same direction. However, if there is a decrease in the power, the operating voltage is changed in the opposite direction. In this method, although MPP cannot be caught completely, an oscillation is made in a range close to MPP. The most important disadvantage of the method is fast changing atmospheric conditions and shading. Since the power obtained from the PV at the time of shading will decrease, the direction in which the operating voltage will be changed may not be determined correctly $[16,40-42]$.

The major disadvantage of the method based on tracking speed and perturbation step is that it oscillates near the 


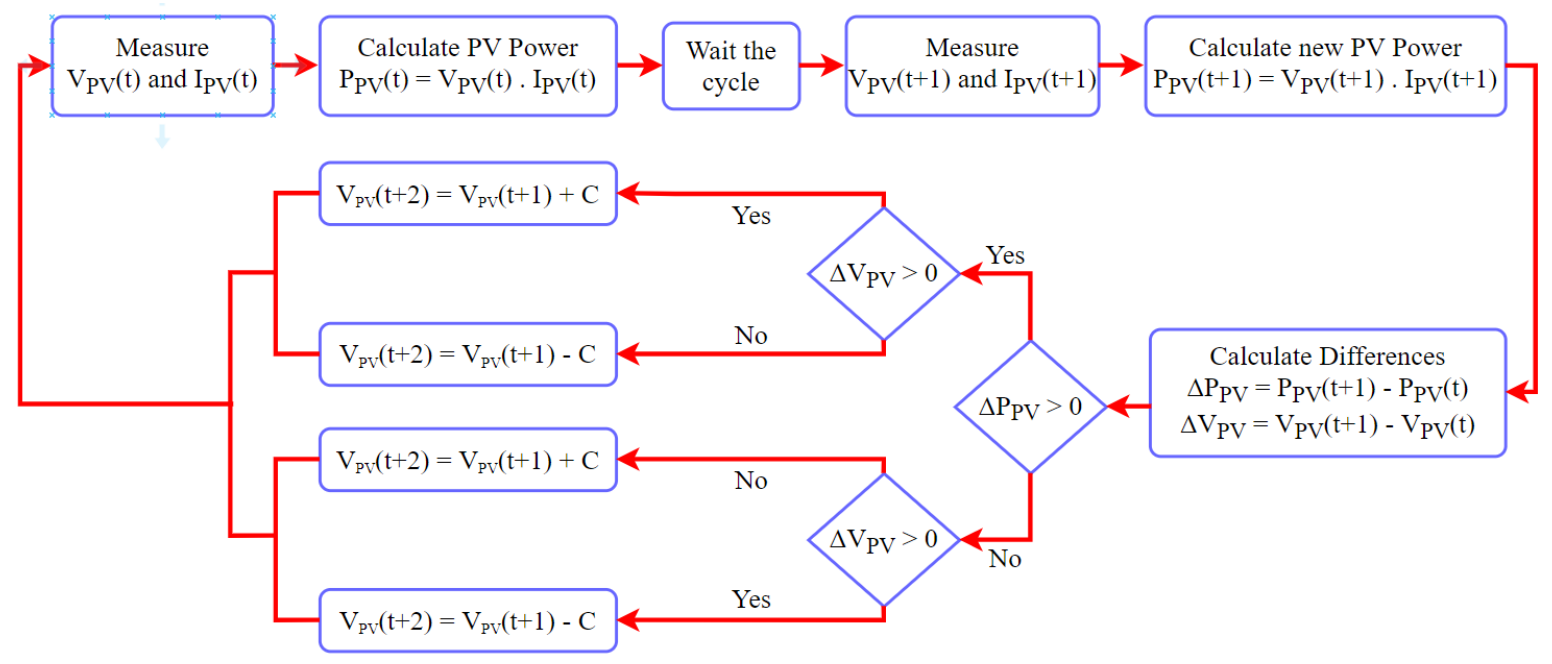

Figure 10. Perturb and observe flowchart

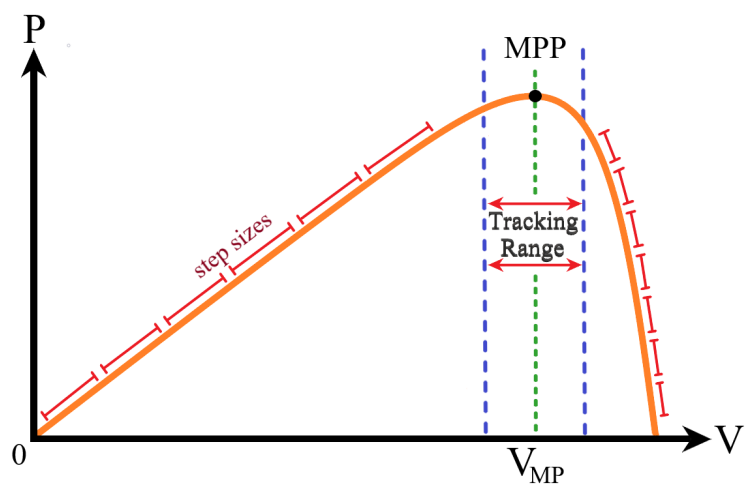

Figure 11. P-V curve of perturb and observe algorithm

MPP instead of capturing the true MPP. When the P-V curve seen in Fig. 11 is examined, it is seen that the power increases almost linearly until the certain value of the voltage and decreases very rapidly after the peak point. In the method, the oscillation around the MPP is minimized with a flexible step size. The step size gets smaller as it gets closer to the MPP and gets bigger as it gets further away. In some studies, the step size is estimated with different algorithms. Thus, a more efficient $\mathrm{P} \& \mathrm{O}$ can be obtained [43-45].

\section{Three-Point Weight Comparison (TPWC)}

TPWC works similarly to $\mathrm{P} \& \mathrm{O}$. The power is calculated by comparing the values at two different moments in $\mathrm{P} \& \mathrm{O}$ and three in TPWC. Since the power of one step ahead and one step behind is calculated and decided accordingly in the PV curve, a closer operation is provided to MPP. Where $\mathrm{X}$ is the current point, $\mathrm{Y}$ is one step ahead and $\mathrm{Z}$ is one step behind, a point is considered positive if it has more power than the previous point, and negative if not. The duty-cycle is increased if two of the points are positively weighted, is decreased if negative. The closest point to MPP is reached when the total weight is zero [3]. In Fig. 12, the flowchart of TPWC and possible nine situations for three points are given. Here, the blue, green, and black colored circles represent the $\mathrm{X}, \mathrm{Y}$, and $\mathrm{Z}$ positions, respectively.,

Figure 12. Three-point weight comparison flowchart 


\section{Hill Climbing $(H C)$}

The flowchart of the HC is shown in Fig. 13. In the HC method, which operates similarly $\mathrm{P} \& \mathrm{O}$, the duty cycle is changed directly instead of changing the current or voltage as in the $\mathrm{P} \& \mathrm{O}$. In the $\mathrm{HC}$, the duty cycle $\mathrm{D}$ is periodically adjusted with an offset (constant perturbation) with the direction of increase in power. If the power change is negative, the perturbation direction is reversed. Fixed or variable step size can be determined as in $\mathrm{P} \& \mathrm{O}$. Similarly, not reaching true MPP under partial shading is seen as the major disadvantage $[46,47]$.

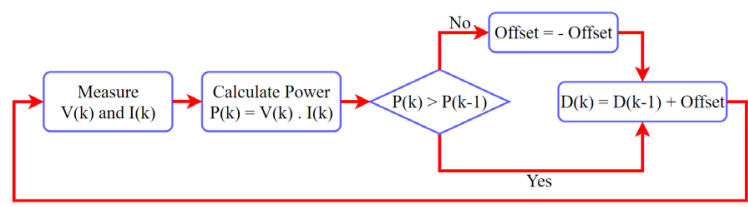

Figure 13. Hill climbing flowchart

\section{On-Line MPP Search (OLMPP)}

In the OLMPP, the maximum power error is found by comparing the instant power with the reference maximum power value, and this error is approached to zero to reach MPP. The method, whose flowchart is given in Fig. 14, has been created based on the operating power of the load. Initial reference values are taken as $P_{\text {ref }}=0$, $\mathrm{I}_{\text {ref }}=0$ and $\mathrm{V}_{\text {ref }}=\mathrm{V}_{\text {oc }}$. The output voltage is controlled by the load current. Therefore, deviations from MPP occur if the load current or power is low. Additional load connections can be made to prevent this situation, but this causes losses. Another disadvantage of the method is that it adapts slowly to changing atmospheric conditions [48].

\section{DC-Link Capacitor (DCLC)}

In this method, a converter $(\mathrm{AC})$ is connected to the PV system. The basic structure of DCLC is shown in Fig. 15, is based on the voltage drop on a capacitor connected to the output of the DC-DC converter. The relationship between the $V_{P V}$ and the $V_{\text {link }}$ is expressed in the following equation:

$$
D=1-\frac{V_{P V}}{V_{\text {link }}}
$$

where $\mathrm{D}$ is the duty ratio of the ideal boost converter.

The output power so the power obtained from the PV, increases if the output current of the boost converter is increased. If the power needed by the converter does not exceed the maximum $\mathrm{P}_{\mathrm{pv}}$ the output power of the boost converter is kept constant. When the maximum power is exceeded, the voltage on the link capacitor starts to drop. Before this drop, the current $I_{\text {peak }}$ of the converter is at the maximum point and the system is operating at MPP. The current (AC) is used as feedback to prevent the $\mathrm{V}_{\text {link }}$ from falling. The duty cycle $\mathrm{D}$ is regulated to keep Ipeak at maximum $[49,50]$.

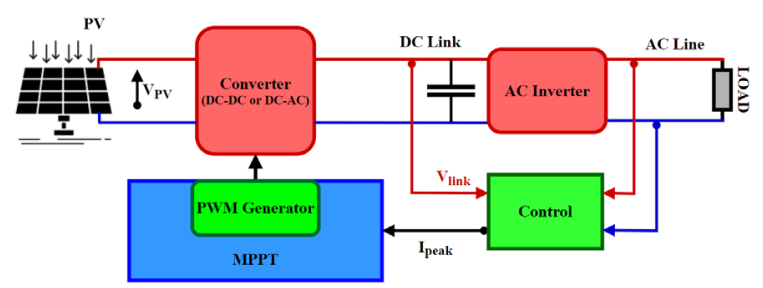

Figure 15. DC-Link capacitor scheme

\section{Incremental Conductance (IncCond)}

The two main disadvantages of the $\mathrm{P} \& \mathrm{O}$ method are the oscillation around MPP and its slowness to adapt to rapidly changing atmospheric conditions. IncCond method has been developed to avoid these disadvantages [14]. By measuring the output voltage and current of the PV, its power and conductivity are computed, and the duty cycle required to operate the system at MPP is determined [17]. The flowchart of the IncCond is given in Fig. 16.

When the ratio of PV power difference to voltage difference is zero, MPP is captured and it can be expressed with the following equations:

$$
\begin{aligned}
& \frac{d P_{P V}}{d V_{P V}}=\frac{d\left(V_{P V} \cdot I_{P V}\right)}{d V_{P V}}=I_{P V}+V_{P V} \frac{d I_{P V}}{d V_{P V}}=0 \\
& \frac{I_{P V}}{V_{P V}}=-\frac{d V_{P V}}{d I_{P V}} \cong-\frac{\Delta V_{P V}}{\Delta I_{P V}}
\end{aligned}
$$

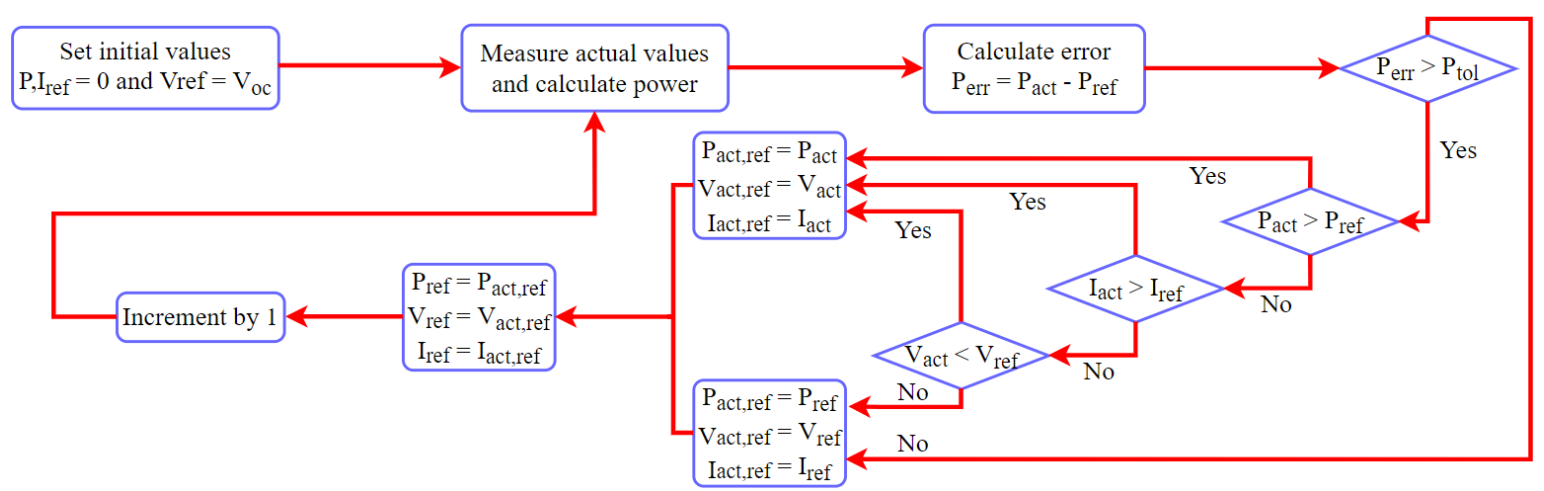

Figure 14. On-line search flowchart 


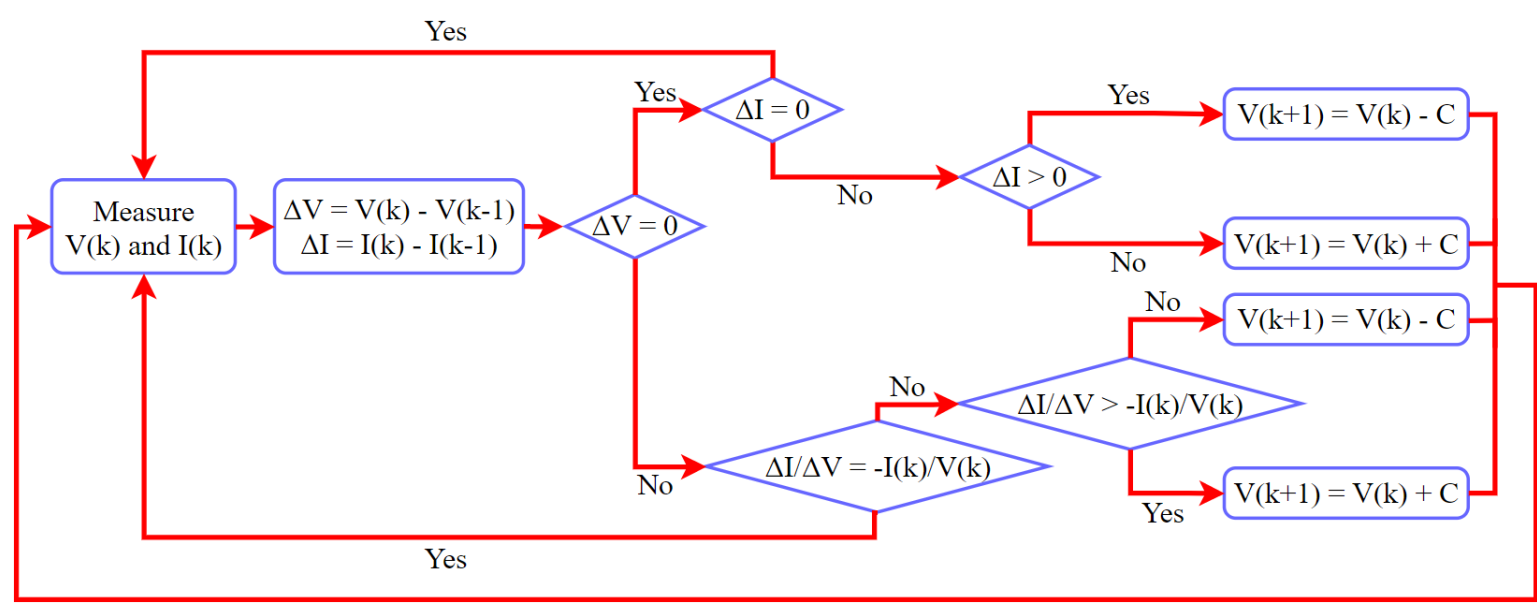

Figure 16. Incremental conductance flowchart

In the P-V curve, the slope is zero in MPP, it increases (positive) on the left of the MPP and decreases on the right (negative):

$$
\begin{aligned}
& \frac{d P_{P V}}{d V_{P V}}=0 \quad \text { if } \quad \frac{d I_{P V}}{d V_{P V}}=-\frac{I_{P V}}{V_{P V}} \quad \text { at MPP } \\
& \frac{d P_{P V}}{d V_{P V}}>0 \quad \text { if } \quad \frac{d I_{P V}}{d V_{P V}}>-\frac{I_{P V}}{V_{P V}} \quad \text { left of MPP } \\
& \frac{d P_{P V}}{d V_{P V}}<0 \quad \text { if } \quad \frac{d I_{P V}}{d V_{P V}}<-\frac{I_{P V}}{V_{P V}} \quad \text { right of MPP }
\end{aligned}
$$

The IncCond method shows the ability to adapt more quickly to sudden changes in atmospheric conditions while narrowing the oscillation around MPP, which are the major disadvantages of $\mathrm{P} \& \mathrm{O}[13,15]$. Although it basically works the same as $\mathrm{P} \& \mathrm{O}$, more complex control structures are used in the IncCond method [16]. Instead of the voltage based on the method, current can also be chosen. In this case, the new method is called Incremental resistance (IncRes) [51,52].

\section{Parasitic Capacitance (PC)}

There are two major reactive parasitic elements in PV cells. These are called parasitic inductance and capacitance. The PC method is very similar to IncCond, but in this method, the parasitic capacitance Cp of the PV cell is also taken into account. Parasitic capacitance is caused by loads in the junction area [53]. If this generally neglected parasitic effect is included in the calculations, the following current equation is obtained:

$$
I_{P V}(t)=I_{p h}-I_{s}\left(e^{\lambda\left(V_{p v}+I_{P V} \cdot R_{s}\right)}-1\right)+I_{c}(t)
$$

Here $I_{c}$ shows the capacitor current and is defined by the following equation:

$$
I_{c}(t)=C_{p} \frac{d V_{P V}}{d t}
$$

The following power equation is obtained by updating Equation (14):

$$
\begin{aligned}
& I_{P V}(t)=F\left(V_{P V}(t)\right)+C_{p} \dot{V}_{P V}(t) \\
& P_{P V}(t)=\left[F\left(V_{P V}(t)\right)+C_{p} \dot{V}_{P V}(t)\right] \cdot V_{P V}(t)
\end{aligned}
$$

Here, if the derivative of PV power to its voltage is taken, the MPP equation is obtained as in the IncCond method. Here the dot represents the degree of the derivative:

$$
\begin{aligned}
& \frac{d P_{P V}(t)}{d V_{P V}(t)}=\frac{d F\left(V_{P V}(t)\right)}{d V_{P V}(t)} \cdot V_{P V}(t)+F\left(V_{P V}(t)\right)=0 \\
& \frac{d F\left(V_{P V}(t)\right)}{d V_{P V}(t)}=-\frac{F\left(V_{P V}(t)\right)}{V_{P V}(t)} \\
& \frac{\dot{I}_{P V}(t)}{\dot{V}_{P V}(t)}=-\frac{I_{P V}(t)}{V_{P V}(t)}
\end{aligned}
$$

In Equation (20), the left side shows incremental conductance, while the right side shows instant conductance. If the second-order derivative is taken, the following maximum power equation is obtained:

$$
\frac{d F\left(V_{P V}(t)\right)}{d V_{P V}(t)}+C\left(\frac{\ddot{V}_{P V}(t)}{\dot{V}_{P V}(t)}+\frac{\dot{V}_{P V}(t)}{V_{P V}(t)}\right)+\frac{F\left(V_{P V}(t)\right)}{V_{P V}(t)}
$$

Here, three expressions refer to incremental inductance, the induced ripple from $C_{p}$, and instantaneous inductance, respectively. If $\mathrm{C}=0$ is taken in this equation, the equality of the IncCond method is obtained. Parasitic capacitance can be modeled as a parallel capacitor to each PV cell, parallel connection of many modules in large-scale systems increases efficiency due to parasitic capacitance $[54,55]$.

\section{Intelligent Methods}

\section{Fuzzy Logic (FL)}

With the development of processor technology, the usage areas of fuzzy logic control have expanded. The use of FL for MPPT provides many advantages. Some of them are to track the MPP with high accuracy, not be affec- 
ted by the disruption of the inputs, and work independently from the system model, unpredictable, and nonmodeling physical data $[19,56]$. The FL method consists of three stages. In the first stage, fuzzification, numerical data are converted into linguistic values with the help of membership function. There are five levels here: $\mathrm{Z}$ (Zero), NS (Negative Small), PS (Positive Small), NB (Negative Big), and PB (Positive Big) [57]. The inputs of the FL algorithm generally consist of functions expressing error $(E)$ and change in error $(\Delta E)$, whose equations are given below:

$$
\begin{gathered}
E=\frac{P_{P V}(t)-P_{P V}(t-1)}{V_{P V}(t)-V_{P V}(t-1)} \\
\Delta E(t)=E(t)-E(t-1)
\end{gathered}
$$

In the second stage, Rule table, entries are processed, and a decision is made. In the last step, defuzzification, linguistic data are transformed into crisp data.

\section{Artificial Neural Networks (ANN)}

ANN generally consist of three layers. The first part, input layer, indicates the part where the data is received, the second part, hidden layer, the part where the data is processed in a complex structure, and the last part, output layer, refers to the part where the obtained results are $[58,59]$. The basic structure of artificial neural networks can be seen in Fig. 17. Input data in neural networks can be PV module parameters such as $\mathrm{I}_{\mathrm{sc}}, \mathrm{V}_{\mathrm{oc}}$, temperature, radiation, atmospheric measurements, or various combinations of these. Duty cycle data that will drive the DC-DC converter is obtained at the output. In this method, input data are processed with certain weights in the hidden layer and it may take days or years to find the ideal weights. Each network structure is trained on the PV system, so it cannot be directly applied to a different system. However, the network trained for a system enables the system to work in true MPPT without being affected by the change of PV module parameters or environmental factors $[20,60,61]$.

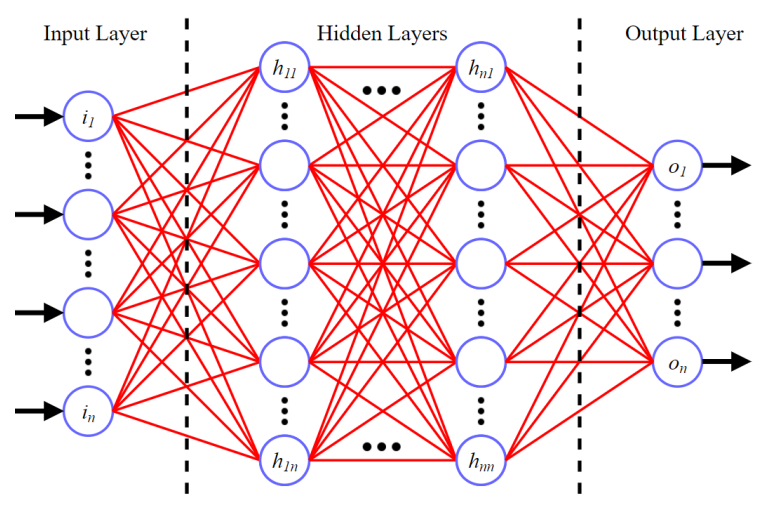

Figure 17. Artificial neural network scheme

\section{Particle Swarm Optimization (PSO)}

PSO is a population-based stochastic method of optimization. There are many different PSO methods created by examining the social behaviors of flocks. In the PSO method, the elements that are part of a flock are randomly distributed into value ranges for optimum solution and the search continues for generations. All members develop their own solutions by simulating the success of their neighbors $[62,63]$. The position $x_{i}$ of an element is calculated by the following equation:

$$
x_{i}^{t+1}=x_{i}^{t}+v_{i}^{t+1}
$$

Here $v_{i}$ is the velocity element showing the step size. If the speed decreases, the control gets slow if the speed increases, the control gets unstable [62]. The next value is calculated with the following equation:

$$
v_{i}^{t+1}=w v_{i}^{t}+c_{1} r_{1}\left(P_{\text {best } i}-x_{i}^{t}\right)+c_{2} r_{2}\left(G_{\text {best }}-x_{i}^{t}\right)
$$

Here $\mathrm{w}$ is the internal weight, $\mathrm{c}_{1,2}$ are the coefficients of acceleration, $r_{1,2}$ are the values in the range of $0-1 . P_{\text {best_i }}$ and $\mathrm{G}_{\text {best_i }}$ represents the best personal position and the best neighborhood position of the particle i, respectively. The most important disadvantage of the PSO is the adjustment of the parameters.

\section{Ant Colony Optimization (ACO)}

The ACO was first introduced in 1990s and applied to some combinational optimization problems sucsesfully [64]. In years, this technique has been more popular for researchers and various applications of ACO have been made [65]. The ACO, probabilistic algorithm, is preferred to find the global optimum paths based on the behavior of foraging ants. Ants move randomly along the paths and explore the area in search of food. While transporting food to the nest, ants leave a trail of chemical pheromones on the way for other ants to reach the food faster. During the action period, the amount of pheromone increases according to the amount of food and this shortens the path to food for the colony [66].

For continuous domains, one of the most common ACO-based algorithms, $\mathrm{ACO}_{\mathrm{R}}$, is based on the Gram Schmidt process. ACO algorithms use a pheromone model to generate probabilistic solutions for combinatorial optimization problems. But $\mathrm{ACO}_{\mathrm{R}}$ uses the solution archive as a way to identify the pheromone distribution over the space of search. A limited number of the complete solutions of the problem are stored in memory called the solution archive. For generating new solutions, the archive acts like a reference [67]. The equations given below are used in ACOR:

$$
G_{i}(x)=\sum_{l=1}^{K} w_{l} g_{l}^{i}(x)=\sum_{l=1}^{K} w_{l} \frac{1}{\sigma_{l}^{i} \sqrt{2 \pi}} \exp \left(-\frac{\left(x-\mu_{l}^{i}\right)^{2}}{2 \sigma_{l}^{i 2}}\right)
$$


Here, $G_{i}(x)$ is the Gaussian Kernel to the i'th dimension of the solution and,$g_{l}^{i}(x)$ is the l'th sub-Gaussian function to the i'th dimension of the solution. $\mu_{l}^{i}$ and $\sigma_{l}^{i}$ are the i'th dimension mean value, and the i'th standard deviation to the l'th solution, respectively. Pheromone equation is:

$$
\tau_{l i(x)}=\frac{1}{\sigma_{l}^{i} \sqrt{2 \pi}} \exp \left(-\frac{\left(x-\mu_{l}^{i}\right)^{2}}{2 \sigma_{l}^{i 2}}\right)
$$

The equation provides the most relevant information to solve the objective function. This $\mathrm{ACO}_{\mathrm{R}}$ model requires many calculations for the right solution. Therefore, processors with high capability and speed are required in the ACO method. This situation increases the cost.

\section{Grey Wolf Optimization (GWO)}

The GWO algorithm mimics the behaviours (hunting and leadership) of wild gray wolves and proposed in 2014 by Mirjalili et al [68]. There are four types of gray wolves in a wolfpack to mimic the leadership hierarchy. These are alpha $(\alpha)$, omega $(\omega)$, delta $(\delta)$, and beta $(\beta)$. When designing the GWO, best to worse solutions are alpha, beta and delta, and omega, respectively. Gray wolves encircle a prey during hunting [69]. This behavior is expressed as

$$
\begin{aligned}
& \vec{D}=\left|\vec{C} \cdot \vec{X}_{p}(t)-\vec{X}_{p}(t)\right| \\
& \vec{X}(t+1)=\vec{X}_{p}(t)-\vec{A} \cdot \vec{D}
\end{aligned}
$$

where $\mathrm{t}$ is the instant iteration, $\vec{D}, \vec{C}$ and $\vec{A}$ are the co- efficients, $\vec{X}_{p}$ is the position of the prey, and $\vec{X}$ is the position of the gray wolf. $\vec{A}$ and $\vec{C}$ are calculated with the equations given below:

$$
\begin{aligned}
& \vec{A}=2 \vec{a} \cdot \vec{r}_{1}-\vec{a} \\
& \vec{C}=2 \vec{r}_{2}
\end{aligned}
$$

The hunt is often led by leaders called alpha and occasionally followed by beta and delta. Thus, alpha is considered as the candidate solution with the best information of the prey location. Delta and omega take the role dealing the wounded members in the wolfpack. Gray wolves finish the hunt by attacking their prey when it gets stuck and stops [70].

The flowchart of the GWO MPPT method for the PV is shown in Fig. 18. For the number of gray wolves, namely the duty ratios, output power $\mathrm{P}_{\mathrm{pv}}$ is computed by the $\mathrm{V}_{\mathrm{pv}}$ and $\mathrm{I}_{\mathrm{pv}}$ measurements. When the MPP is found by the wolves, the correlated coefficient vectors turn into almost zero. In this algorithm duty cycle (D) is described as a grey wolf [71]. In this case, Equation (31) can be modified as given below:

$$
D_{i}(k+1)=D_{i}(k)-A \cdot D
$$

Thereby, the fitness function of the MPPT algorithm has been formulated as follows

$$
P\left(D_{i}^{k}\right)>P\left(D_{i}^{k-1}\right)
$$

where $\mathrm{P}, \mathrm{k}$, and $\mathrm{i}$ are the power, the number of iterations, and the number of present gray wolves, respectively.

Fitness Evaluation

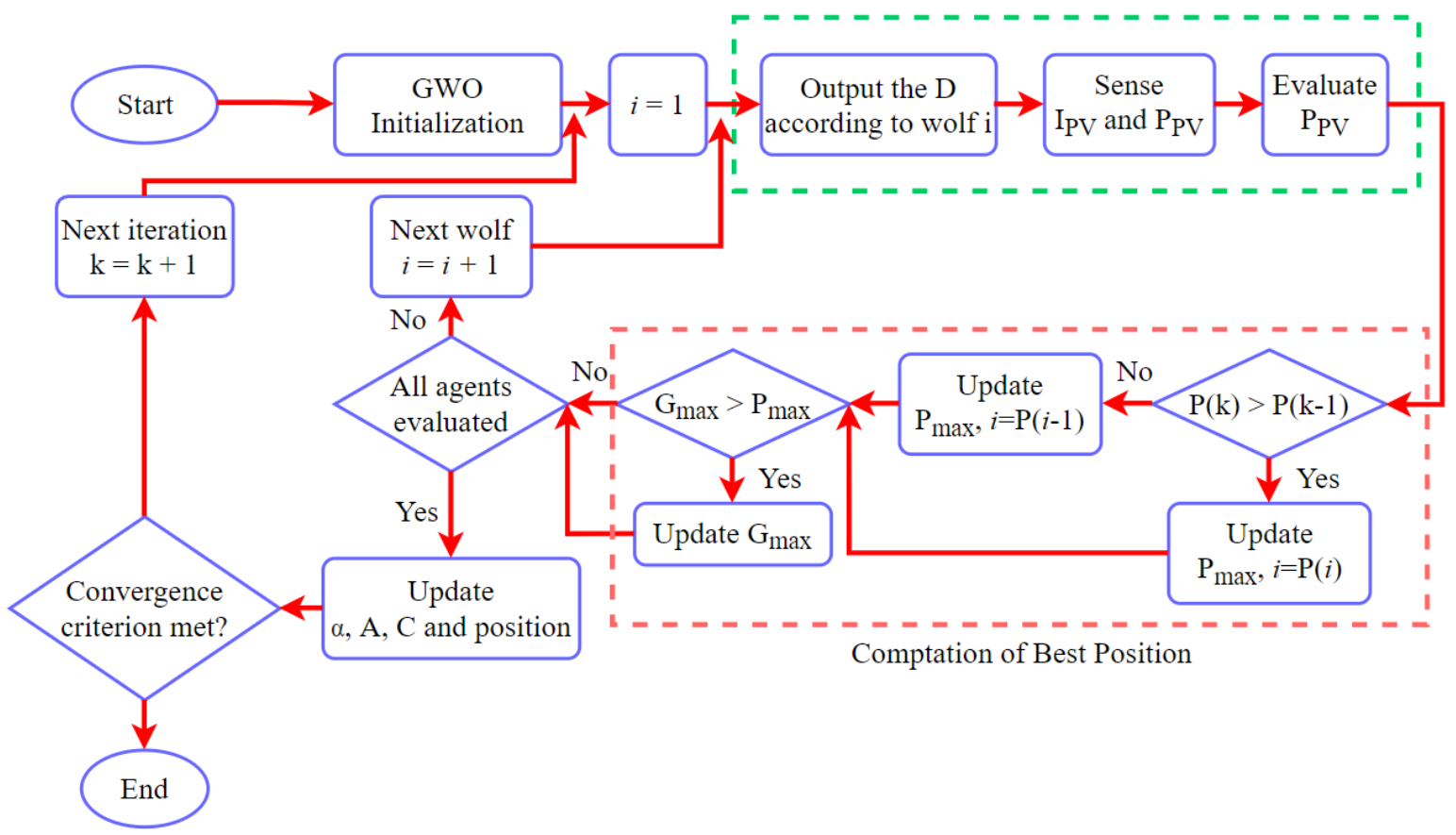

Figure 18. Grey wolf optimization flowchart 


\section{RESULTS AND DISCUSSION}

Numerous MPPT algorithms have been proposed to obtain maximum power and efficiency from the PV panel in years. These methods have many advantages and disadvantages. It is necessary to choose the optimum method for the PV system to be applied. Here, many parameters such as the atmospheric conditions of the region where the system will be installed, sunshine duration, and the budget allocated to the system should be taken into consideration. In this study, the most common methods were examined and compared with reference to certain parameters. Table 1 shows the comparison of the algorithms. While the comparison the major parameters such as speed, stability, cost, efficiency, etc considered into account. Here, 'V' refers to voltage, 'I' current, ' $T$ ' temperature sensor, 'A' analog, and 'D' digital.

MPPT methods can be classified by different names. There are different approaches in these classifications such as the characteristics of the method and the prevalence of use. Generally, they are divided into classes such as indirect, direct, intelligent, conventional methods etc. In the study, a new classification of the most used MPPT algorithms has been made by considering their dates of invention, complexity, and level of development, and is presented in Table 2.

1st generation methods are generally analog methods. These methods are easy to apply, low cost, low efficiency, and cannot track true MPPT. The most important advantage of these methods is that they can track MPP with acceptable speed and accuracy by low cost and fast setup.

Table 2.Classification of MPPT algorithms.

\begin{tabular}{|c|c|}
\hline Generation & Tracking Method \\
\hline \multirow{6}{*}{ 1st Generation } & Constant Voltage \\
\hline & Fractional Open-Circuit Voltage \\
\hline & Open-Circuit Voltage Pilot PV Cell \\
\hline & Fractional Short-Circuit Current \\
\hline & Look Up Table \\
\hline & Load Current or Load Voltage Maximization \\
\hline \multirow{8}{*}{ 2nd Generation } & PVOutput Senseless \\
\hline & Perturb\&Obsevre \\
\hline & Three-Point Weight Comparison \\
\hline & Hill Climbing \\
\hline & On-Line MPP Search \\
\hline & DC-Link Capacitor Drop Control \\
\hline & Incremental Conductance \\
\hline & Parasitic Capacitance \\
\hline \multirow{5}{*}{ 3rd Generation } & Fuzzy Logic Control \\
\hline & Artificial Neural Networks \\
\hline & Particle Swarm Optimization \\
\hline & Ant Colony Optimization \\
\hline & Grey Wolf Optimization \\
\hline
\end{tabular}

Table 1.Comparison of MPPT algorithms.

\begin{tabular}{|c|c|c|c|c|c|c|c|c|}
\hline Tracking Method & Sensors & Stability & $A / D$ & Speed & True MPPT & Cost & Efficiency & Ref \\
\hline$C V$ & $v$ & Low & $A$ & Mid & No & Low & Low & [72] \\
\hline FOCV & $v$ & Low & $A$ & Mid & No & Low & Low & [73] \\
\hline FOCVPVC & $v$ & Low & $A$ & Mid & No & Low & Low & [74] \\
\hline FSCC & $v$ & Low & $A$ & Mid & No & Low & Low & [75] \\
\hline LUT & $T \& I$ & Low & $D$ & Mid & Maybe & Mid & Mid & [76] \\
\hline LCLVM & $V \& I$ & Low & $A$ & Low & No & Low & Low & [77] \\
\hline POS & 1 & Low & $D$ & Low & No & Low & Low & [78] \\
\hline$P \& O$ & $V \& I$ & Low & $A / D$ & Low & Yes & Mid & Mid & [79] \\
\hline$T P W C$ & $V \& I$ & Mid & $D$ & Mid & Yes & Mid & Mid & [8o] \\
\hline$H C$ & $V \& I$ & Mid & $D$ & Low & Yes & Mid & Mid & [81] \\
\hline OLMPP & $V \& I$ & Mid & $D$ & Low & Yes & Mid & Mid & [82] \\
\hline$D C L C$ & $V \& I$ & Mid & $D$ & Low & No & Low & Low & [83] \\
\hline IncCond & $V \& I$ & Mid & $D$ & Low & Yes & Mid & Mid & [84] \\
\hline$P C$ & $V \& I$ & Mid & $D$ & Mid & Yes & High & Mid & [85] \\
\hline$F L$ & $V \& I$ & High & $D$ & High & Yes & High & High & [21] \\
\hline ANN & $V \& I$ & High & $D$ & High & Yes & High & High & [86] \\
\hline PSO & $V \& I$ & High & $D$ & High & Yes & High & High & [87] \\
\hline$A C O$ & $V \& I$ & High & $D$ & High & Yes & High & High & [88] \\
\hline GWO & $V \& I$ & High & $D$ & High & Yes & High & High & [89] \\
\hline
\end{tabular}


2nd generation methods, the most widely used, are usually digital systems that require more than one sensor. In some methods of this generation, true MPPT can be achieved in medium level stability, speed, cost, and efficiency.

3rd generation methods, which especially emerged with the development of digital electronics, high-speed processors, and optimization theories, has quite high speed, complexity, stability, cost, and efficiency. For the successful implementation of these methods, it should be ensured that many iterations are made quickly, and the right decision is made. Therefore, it is necessary to use processors with high processing speed, but this also means an increase in cost.

\section{CONCLUSION}

Considering the damage caused by fossil fuels to the environment, researches are carried out for cleaner energy resources. At this point, solar energy, which has an infinite source, also draws attention due to its eco friendliness. A great number of MPPT algorithms have been proposed in order to obtain maximum power and efficiency from PV panels. In this study, MPPT algorithms which are well accepted in the literature and widely used in the industry were examined and a detailed comparison table was presented. A new classification has been proposed for the analyzed MPPT algorithms. It is thought that this review can help in choosing the optimum algorithm for a PV system and can serve as a significant reference to future studies in this field.

\section{CONFLICT OF INTEREST}

Authors approve that to the best of their knowledge, there is not any conflict of interest or common interest with an institution/organization or a person that may affect the review process of the paper.

\section{AUTHOR CONTRIBUTION}

Omer Faruk Tozlu: Writing-review \& editing, Methodology, Conseptualization. Huseyin Calik: Methodology, Conseptualization, Supervision.

\section{REFERENCES}

1. Rabaia MKH, Abdelkareem MA, Sayed ET, Elsaid K, Chae KJ, Wilberforce T, et al. Environmental impacts of solar energy systems: A review. Sci Total Environ 2021;754:141989. https://doi. org/10.1016/j.scitotenv.2020.141989.

2. Motahhir S, El Hammoumi A, El Ghzizal A. The most used MPPT algorithms: Review and the suitable low-cost embedded board for each algorithm. J Clean Prod 2020;246:118983. https://doi. org/10.1016/j.jclepro.2019.118983

3. Bahrami M, Zandi M, Gavagsaz R, Nahid-Mobarakeh B,
Pierfederici S. A New Hybrid Method of MPPT for Photovoltaic Systems Based on FLC and Three Point-Weight Methods. Int. J. Adv. Sci. Technol., IEEE; 2016, p. 446-50.

4. Kumar M, Ban DK, Kim J. Photo-induced pyroelectric spikes for neuromorphic sensors. Mater Lett 2018;225:46-9. https://doi. org/10.1016/j.matlet.2018.04.106.

5. Lorenzo E. Solar electricity: engineering of photovoltaic systems. Earthscan/James \& James; 1994.

6. Qi C, Ming Z. Photovoltaic Module Simulink Model for a Standalone PV System. Phys Procedia 2012;24:94-100. https://doi. org/10.1016/j.phpro.2012.02.015.

7. Kumar N, Hussain I, Singh B, Panigrahi BK. Framework of Maximum Power Extraction from Solar PV Panel Using Self Predictive Perturb and Observe Algorithm. IEEE Trans Sustain Energy 2018;9:895-903. https://doi.org/10.1109/ TSTE.2017.2764266.

8. Motahhir S, El Hammoumi A, El Ghzizal A. Photovoltaic system with quantitative comparative between an improved MPPT and existing INC and P\&O methods under fast varying of solar irradiation. Energy Reports 2018;4:341-50. https://doi.org/10.1016/j. egyr.2018.04.003.

9. Teshome DF, Lee CH, Lin YW, Lian KL. A modified firefly algorithm for photovoltaic maximum power point tracking control under partial shading. IEEE J Emerg Sel Top Power Electron 2017;5:661-71. https://doi.org/10.1109/JESTPE.2016.2581858.

10. Femia N, Petrone G, Spagnuolo G, Vitelli M. Power Electronics and Control Techniques for Maximum Energy Harvesting in Photovoltaic Systems. CRC Press, Taylor \& Francis Group; 2017. https://doi.org/10.1201/b14303.

11. Christopher Iw, Assistant Professor S. Comparative Study of P\&O and InC MPPT Algorithms. Am J Eng Res 2013;02:402-8.

12. Kota VR, Bhukya MN. A novel linear tangents based $\mathrm{P} \& \mathrm{O}$ scheme for MPPT of a PV system. Renew Sustain Energy Rev 2017;71:25767. https://doi.org/10.1016/j.rser.2016.12.054.

13. Ishaque K, Salam Z, Lauss G. The performance of perturb and observe and incremental conductance maximum power point tracking method under dynamic weather conditions. Appl Energy 2014;119:228-36. https://doi.org/10.1016/j.apenergy.2013.12.054.

14. Wasynczuk O. Dynamic Behavior of a Class of Photovoltaic Power Systems. IEEE Trans Power Appar Syst 1983;PAS-102:3031-7.

15. Safari A, Mekhilef S. Simulation and hardware implementation of incremental conductance MPPT with direct control method using cuk converter. IEEE Trans Ind Electron 2011;58:1154-61. https:// doi.org/10.1109/TIE.2010.2048834.

16. Elgendy MA, Zahawi B, Atkinson DJ. Assessment of the incremental conductance maximum power point tracking algorithm. IEEE Trans Sustain Energy 2013;4:108-17. https://doi.org/10.1109/ TSTE.2012.2202698.

17. Tey KS, Mekhilef S. Modified incremental conductance MPPT algorithm to mitigate inaccurate responses under fast-changing solar irradiation level. Sol Energy 2014;101:333-42. https://doi. org/10.1016/j.solener.2014.01.003.

18. Shengqing L, Fujun L, Jian Z, Wen C, Donghui Z. An improved MPPT control strategy based on incremental conductance method. Soft Comput 2020;24:6039-46. https://doi.org/10.1007/s00500020-04723-z.

19. Algarín CR, Giraldo JT, Álvarez OR. Fuzzy logic based MPPT controller for a PV system. Energies 2017;10. https://doi.org/10.3390/ en10122036.

20. Bendib B, Krim F, Belmili H, Almi MF, Bolouma S. An intelligent MPPT approach based on neural-network voltage estimator and fuzzy controller, applied to a stand-alone PV system. IEEE Int. 
Symp. Ind. Electron., IEEE; 2014, p. 404-9. https://doi.org/10.1109/ ISIE.2014.6864647.

21. Yilmaz U, Kircay A, Borekci S. PV system fuzzy logic MPPT method and PI control as a charge controller. Renew Sustain Energy Rev 2018;81:994-1001. https://doi.org/10.1016/j.rser.2017.08.048.

22. Bollipo RB, Mikkili S, Bonthagorla PK. Critical Review on PV MPPT Techniques: Classical, Intelligent and Optimisation. IET Renew Power Gener 2020;14:1433-52. https://doi.org/10.1049/ietrpg.2019.1163.

23. Joshi P, Arora S. Maximum power point tracking methodologies for solar PV systems - A review. Renew Sustain Energy Rev 2017;70:1154-77. https://doi.org/10.1016/j.rser.2016.12.019.

24. Bendib B, Belmili H, Krim F. A survey of the most used MPPT methods: Conventional and advanced algorithms applied for photovoltaic systems. Renew Sustain Energy Rev 2015;45:637-48 https://doi.org/10.1016/j.rser.2015.02.009.

25. Karami N, Moubayed N, Outbib R. General review and classification of different MPPT Techniques. Renew Sustain Energy Rev 2017;68:1-18. https://doi.org/10.1016/j.rser.2016.09.132.

26. Asim M, Tariq M, Mallick MA, Ashraf I. An improved constant voltage based MPPT technique for PMDC motor. Int J Power Electron Drive Syst 2016;7:1330-6. https://doi.org/10.11591/ijpeds. v7i4.pp1330-1336.

27. Ahmad J. A fractional open circuit voltage based maximum power point tracker for photovoltaic arrays. ICSTE 2010 - 2010 2nd Int. Conf. Softw. Technol. Eng. Proc., vol. 1, IEEE; 2010, p. 247-50 https://doi.org/10.1109/ICSTE.2010.5608868.

28. Enslin JHR, Wolf MS, Snyman DB, Swiegers W. Integrated photovoltaic maximum power point tracking converter. IEEE Trans Ind Electron 1997;44:769-73. https://doi.org/10.1109/41.649937.

29. Lopez-Lapeña O, Penella MT. Low-power FOCV MPPT controller with automatic adjustment of the sample\&hold. Electron Lett 2012;48:1301-3. https://doi.org/10.1049/el.2012.1345

30. Weddell AS, Merrett G V., Al-Hashimi BM. Ultra low-power photovoltaic MPPT technique for indoor and outdoor wireless sensor nodes. Proc. -Design, Autom. Test Eur. DATE, IEEE; 2011, p. 905-8. https://doi.org/10.1109/date.2011.5763302.

31. Sandali A, Oukhoya T, Cheriti A. Modeling and Design ofPV Grid Connected System Using a Modified Fractional Short-Circuit Current MPPT. 2014 Int. Renew. Sustain. Energy Conf., IEEE; 2014, p. 224-9. https://doi.org/10.1109/IRSEC.2014.7059859.

32. Masoum MAS, Dehbonei H, Fuchs EF. Theoretical and experimental analyses of photovoltaic systems with voltage and current-based maximum power point tracking. IEEE Trans Energy Convers 2004;19:652-3. https://doi.org/10.1109/TEC.2004.832449.

33. Sher HA, Murtaza AF, Noman A, Addoweesh KE, Al-Haddad K, Chiaberge M. A New Sensorless Hybrid MPPT Algorithm Based on Fractional Short-Circuit Current Measurement and P\&O MPPT. IEEE Trans Sustain Energy 2015;6:1426-34. https://doi.org/10.1109/ TSTE.2015.2438781.

34. Sankar M, Ramaprabha R. MODELLING AND SIMULATION OF MATLAB / SIMULINK BASED LOOKUP TABLE. ARPN J Eng Appl Sci 2013;8:948-53.

35. Kota VR, Bhukya MN. A simple and efficient MPPT scheme for PV module using 2-Dimensional lookup table. 2016 IEEE Power Energy Conf. Illinois, PECI 2016, IEEE; 2016, p. 2-8. https://doi. org/10.1109/PECI.2016.7459226.

36. Wang $H$, Vinayagam L, Jiang $H$, Cai ZQ, Ni Q, Li H. A new MPPT technique for the maximization of overall system output in solar generation. Proc Int Conf Power Electron Drive Syst 2015;2015-Augus:791-5. https://doi.org/10.1109/ PEDS.2015.7203540
37. Sanjeevikumar P, Grandi G, Wheeler PW, Blaabjerg F, Loncarski J. A simple MPPT algorithm for novel PV power generation system by high output voltage DC-DC boost converter. IEEE Int. Symp Ind. Electron., vol. September, IEEE; 2015, p. 214-20. https://doi. org/10.1109/ISIE.2015.7281471.

38. Almutairi A, Abo-Khalil AG, Sayed K, Albagami N. MPPT for a PV grid-connected system to improve efficiency under partial shading conditions. Sustainability 2020;12:1-18. https://doi.org/10.3390/ su122410310.

39. Kim SY, Park S, Jang SJ, Kim GH, Seo HR, Yu K. An effective POS MPPT control method for PV power generation system. Proc. 12th Int. Conf. Electr. Mach. Syst. ICEMS 2009, IEEE; 2009, p. 1-6. https://doi.org/10.1109/ICEMS.2009.5382688.

40. Femia N, Petrone G, Spagnuolo G, Vitelli M. Optimization of perturb and observe maximum power point tracking method. IEEE Trans Power Electron 2005;20:963-73. https://doi.org/10.1109/ TPEL.2005.850975.

41. Nedumgatt JJ, Jayakrishnan KB, Umashankar S, Vijayakumar D, Kothari DP. Perturb and observe MPPT algorithm for solar PV systems-modeling and simulation. Proc - 2011 Annu IEEE India Conf Eng Sustain Solut INDICON-2011 2011. https://doi. org/10.1109/INDCON.2011.6139513.

42. Sera D, Mathe L, Kerekes T, Spataru SV, Teodorescu R. On the perturb-and-observe and incremental conductance mppt methods for PV systems. IEEE J Photovoltaics 2013;3:1070-8. https://doi. org/10.1109/JPHOTOV.2013.2261118

43. Femia N, Granozio D, Petrone G, Spagnuolo G, Vitelli M. Predictive \& adaptive MPPT perturb and observe method. IEEE Trans Aerosp Electron Syst 2007;43:934-50. https://doi.org/10.1109/ TAES.2007.4383584

44. Piegari L, Rizzo R. Adaptive perturb and observe algorithm for photovoltaic maximum power point tracking. IET Renew Power Gener 2010;4:317-28. https://doi.org/10.1049/iet-rpg.2009.0006.

45. Abdelsalam AK, Massoud AM, Ahmed S, Enjeti PN. Highperformance adaptive Perturb and observe MPPT technique for photovoltaic-based microgrids. IEEE Trans Power Electron 2011;26:1010-21. https://doi.org/10.1109/TPEL.2011.2106221.

46. Bahari MI, Tarassodi P, Naeini YM, Khalilabad AK, Shirazi P. Modeling and Simulation Of Hill Climbig MPPT Algorithm For Photovoltaic Application. Int. Symp. Power Electron. Electr. Drives, Autom. Motion, IEEE; 2016, p. 1041-4.

47. Xiao W, Dunford WG. A Modified Adaptive Hill Climbing MPPT Method for Photovoltaic Power Systems. 35th Annu. IEEE Power Electron. Spec. Conf., Aachen, Germany: 2004, p. 1957-63.

48. Altas IH, Sharaf AM. A Novel On-Line MPP Search Algorithm For PV Arrays. IEEE Trans Energy Convers 1996;11:748-54.

49. Kitano T, Matsui M, Xu D hong. Power sensor-less MPPT control scheme utilizing power balance at DC link system design to ensure stability and response. IECON Proc. (Industrial Electron. Conf., vol. 2, 2001, p. 1309-14. https://doi.org/10.1109/iecon.2001.975971.

50. Shi Y, Li R, Xue Y, Li H. High-frequency-link-based grid-tied PV system with small DC-link capacitor and low-frequency ripplefree maximum power point tracking. IEEE Trans Power Electron 2016;31:328-39. https://doi.org/10.1109/TPEL.2015.2411858.

51. Mei Q, Shan M, Liu L, Guerrero JM. A novel improved variable step-size incremental-resistance MPPT method for PV systems. IEEE Trans Ind Electron 2011;58:2427-34. https://doi.org/10.1109/ TIE.2010.2064275.

52. Lee JH, Bae HS, Cho BH. Advanced incremental conductance MPPT algorithm with a variable step size. EPE-PEMC 2006 12th Int. Power Electron. Motion Control Conf. Proc., 2007, p. 603-7. https://doi.org/10.1109/EPEPEMC.2006.283227. 
53. Brambilla A, Gambarara M, Garutti A, Ronchi F. New approach to photovoltaic arrays maximum power point tracking. PESC Rec - IEEE Annu Power Electron Spec Conf 1999;2:632-7. https://doi. org/10.1109/PESC.1999.785575.

54. Takashima T, Tadayoshi T, Amano M, Ando Y. Maximum Output Control of Photovoltaic (PV) Array. Collect. Tech. Pap. 35th Intersoc. Energy Convers. Eng. Conf. Exhib., 2000, p. 380-3.

55. Spiazzi G, Buso S, Mattavelli P. Analysis of MPPT algorithms for photovoltaic panels based on ripple correlation techniques in presence of parasitic components. 2009 Brazilian Power Electron Conf COBEP2009 2009:88-95. https://doi.org/10.1109/ COBEP.2009.5347738

56. Al Nabulsi A, Dhaouadi R. Efficiency optimization of a dsp-based standalone PV system using fuzzy logic and dual-MPPT control IEEE Trans Ind Informatics 2012;8:573-84. https://doi.org/10.1109/ TII.2012.2192282.

57. Algazar MM, Al-Monier H, El-Halim HA, Salem MEEK Maximum power point tracking using fuzzy logic control. Int J Electr Power Energy Syst 2012;39:21-8. https://doi.org/10.1016/j. ijepes.2011.12.006.

58. Messalti S, Harrag AG, Loukriz AE. A new neural networks MPPT controller for PV systems. 2015 6th Int. Renew. Energy Congr. IREC 2015, IEEE; 2015. https://doi.org/10.1109/IREC.2015.7110907.

59. Ocran TA, Cao J, Cao B, Sun X. Artificial neural network maximum power point tracker for solar electric vehicle. Tsinghua Sci Technol 2005;10:204-8. https://doi.org/10.1016/S1007-0214(05)70055-9.

60. Heidari M. Improving efficiency of photovoltaic system by using neural network MPPT and predictive control of converter. Int J Renew Energy Res 2016;6:1524-9.

61. Ramaprabha R, Mathur BL, Sharanya M. Solar array modeling and simulation of MPPT using neural network. 2009 Int. Conf. Control Autom. Commun. Energy Conserv. INCACEC 2009, IEEE; 2009, p. $1-5$.

62. de Oliveira FM, Oliveira da Silva SA, Durand FR, Sampaio LP, Bacon VD, Campanhol LBG. Grid-tied photovoltaic system based on PSO MPPT technique with active power line conditioning. IET Power Electron 2016;9:1180-91. https://doi.org/10.1049/iet-pel.2015.0655.

63. Renaudineau H, Donatantonio F, Fontchastagner J, Petrone G Spagnuolo G, Martin JP, et al. A PSO-based global MPPT technique for distributed PV power generation. IEEE Trans Ind Electron 2015;62:1047-58. https://doi.org/10.1109/TIE.2014.2336600.

64. Dorigo M, Maniezzo V, Colorni A. Ant system: Optimization by a colony of cooperating agents. IEEE Trans Syst Man, Cybern Part B Cybern 1996;26:29-41. https://doi.org/10.1109/3477.484436.

65. Dorigo $M$, Birattari $M$, Stützle $T$. Ant colony optimization. IEEE Comput Intell Mag 2006:28-39. https://oi.org/10.4249/ scholarpedia.1461

66. Satheesh Krishnan G, Kinattingal S, Simon SP, Nayak PSR. MPPT in PV systems using ant colony optimisation with dwindling population. IET Renew Power Gener 2020;14:1105-12. https://doi. org/10.1049/iet-rpg.2019.0875.

67. Titri S, Larbes C, Toumi KY, Benatchba K. A new MPPT controller based on the Ant colony optimization algorithm for Photovoltaic systems under partial shading conditions. Appl Soft Comput J 2017;58:465-79. https://doi.org/10.1016/j.asoc.2017.05.017.

68. Mirjalili S, Mirjalili SM, Lewis A. Grey Wolf Optimizer Adv Eng Softw 2014;69:46-61. https://doi.org/10.1016/j. advengsoft.2013.12.007.

69. Eshak MM, Khafagy MA, Makeen P, Abdellatif SO. Optimizing the performance of a stand-alone PV system under non-uniform irradiance using Gray-Wolf and hybrid neural network AI-MPPT algorithms. 2nd Nov. Intell. Lead. Emerg. Sci. Conf. NILES 2020
2020, p. 600-5. https://doi.org/10.1109/NILES50944.2020.9257965.

70. Tjahjono A, Anggriawan DO, Habibi MN, Prasetyono E. Modified grey wolf optimization for maximum power point tracking in photovoltaic system under partial shading conditions. Int Electr Eng Informatics 2020;12:94-104. https://doi.org/10.15676/ ijeei.2020.12.1.8.

71. Guo K, Cui L, Mao M, Zhou L, Zhang Q. An Improved Gray Wolf Optimizer MPPT Algorithm for PV System with BFBIC Converter under Partial Shading. IEEE Access 2020;8:103476-90. https://doi. org/10.1109/ACCESS.2020.2999311.

72. Lasheen M, Rahman AKA, Abdel-Salam M, Ookawara S. Performance Enhancement of Constant Voltage Based MPPT for Photovoltaic Applications Using Genetic Algorithm. Energy Procedia 2016;100:217-22. https://doi.org/10.1016/j. egypro.2016.10.168

73. Huang YP, Hsu SY. A performance evaluation model of a high concentration photovoltaic module with a fractional open circuit voltage-based maximum power point tracking algorithm. Comput Electr Eng 2016;51:331-42. https://doi.org/10.1016/j. compeleceng.2016.01.009.

74. Baimel D, Tapuchi S, Levron Y, Belikov J. Improved fractional open circuit voltage MPPT methods for PV systems. Electron 2019;8:120. https://doi.org/10.3390/electronics8030321.

75. Sher HA, Murtaza AF, Noman A, Addoweesh KE, Chiaberge M. An intelligent control strategy of fractional short circuit current maximum power point tracking technique for photovoltaic applications. J Renew Sustain Energy 2015;7. https://doi. org/10.1063/1.4906982.

76. Ilyas A, Khan MR, Ayyub M. Lookup Table Based Modeling and Simulation of Solar Photovoltaic System. 2015 Annu. IEEE India Conf., IEEE; 2015, p. 14-9.

77. Zhang L, Wang Z, Cao P, Zhang S. A maximum power poin tracking algorithm of load current maximization-perturbation and observation method with variable step size. Symmetry (Basel) 2020;12:1-16. https://doi.org/10.3390/sym12020244.

78. Lee SJ, Park HY, Kim GH, Seo HR, Ali MH, Park M, et al. The experimental analysis of the gridconnected PV system applied by POS MPPT. Proceeding Int. Conf. Electr. Mach. Syst. ICEMS 2007, 2007, p. 1786-91. https://doi.org/10.1109/ICEMS.2007.4412095.

79. Killi M, Samanta S. Modified perturb and observe MPPT algorithm for drift avoidance in photovoltaic systems. IEEE Trans Ind Electron 2015;62:5549-59. https://doi.org/10.1109/TIE.2015.2407854.

80. Roy CP, Naick BK, Shankar G. Modified three-point weight comparison method for adaptive MPPT of photovoltaic systems. IET Conf. Publ., vol. 2013, 2013, p. 146-56. https://doi.org/10.1049/ cp.2013.2184.

81. Liu F, Kang Y, Yu Z, Duan S. Comparison of P\&O and Hill Climbing MPPT Methods for Grid-Connected PV Converter. 2008 3rd IEEE Conf. Ind. Electron. Appl. ICIEA 2008, 2008, p. 804-7. https://doi. org/10.1109/ICIEA.2008.4582626.

82. Altas IH, Sharaf AM. A Novel Photovoltaic On-Line Search Algorithm for Maximum Energy Utilization. Int. Conf. Commun., Oman: Computer and Power (ICCCP'07); 2007, p. 192-7.

83. Shi Y, Liu L, Li H, Xue Y. A single-phase grid-connected PV converter with minimal DC-link capacitor and low-frequency ripple-free maximum power point tracking. 2013 IEEE Energy Convers. Congr. Expo. ECCE 2013, IEEE; 2013, p. 2385-90. https:// doi.org/10.1109/ECCE.2013.6647006.

84. Tey KS, Mekhilef S. Modified incremental conductance algorithm for photovoltaic system under partial shading conditions and load variation. IEEE Trans Ind Electron 2014;61:5384-92. https://doi. org/10.1109/TIE.2014.2304921 
85. Hohm DP, Ropp ME. Comparative study of maximum power point tracking algorithms. Prog Photovoltaics Res Appl 2003;11:47-62. https://doi.org/10.1002/pip.459.

86. Messalti S, Harrag A, Loukriz A. A new variable step size neural networks MPPT controller: Review, simulation and hardware implementation. Renew Sustain Energy Rev 2017;68:221-33. https:// doi.org/10.1016/j.rser.2016.09.131.

87. Ishaque K, Salam Z, Amjad M, Mekhilef S. An improved particle swarm optimization (PSO)-based MPPT for PV with reduced steady-state oscillation. IEEE Trans Power Electron 2012;27:362738. https://doi.org/10.1109/TPEL.2012.2185713.

88. Jiang LL, Maskell DL, Patra JC. A novel ant colony optimizationbased maximum power point tracking for photovoltaic systems under partially shaded conditions. Energy Build 2013;58:227-36. https://doi.org/10.1016/j.enbuild.2012.12.001.

89. Mohanty S, Subudhi B, Ray PK. A Grey Wolf-Assisted Perturb \& Observe MPPT Algorithm for a PV System. IEEE Trans Energy Convers 2017;32:340-7. https://doi.org/10.1109/TEC.2016.2633722. 